\title{
Contributions of Ethnography for understanding the training process of In-service Physics teachers*
}

\section{Contribuciones de la etnografía a la comprensión del proceso de formación de profesores de Física en servicio}

\author{
Liliana Tarazona Vargas ${ }^{1}$. https://orcid.org/0000-0003-3752-3879 \\ Antonia Candela ${ }^{2}$. https://orcid.org/0000-0002-9001-4451
}

\begin{abstract}
This paper presents the results of an ethnographic study of two in-service physics teachers' participation in a seminar of the master's degree program on teaching science they are studying at the National Pedagogical University (UPN in Spanish) in Bogotá, Colombia. In it the two teachers work with an advisor to plan, implement and report the results of an educational proposal aimed at secondary school students. The ethnographic analysis yields elements for reflecting on continuing teacher education: the multiple meanings contained in the teachers' practices and shared assumptions; the work undertaken jointly between the teachers to explain, confront and negotiate these meanings; and the teachers' commitment to their students' development.
\end{abstract}

Keywords: In-service teacher education. Teaching practice. Cooperative planning, Ethnography.

Resumen: Se presentan resultados de un estudio etnográfico sobre la participación de dos profesores de física en servicio en uno de los seminarios de la maestría que cursan en Docencia de las Ciencias Naturales en la Universidad Pedagógica Nacional (UPN) en Bogotá, Colombia. Se analiza cómo ambos profesores junto con una asesora planean, implementan y narran los resultados de una propuesta didáctica dirigida a estudiantes de secundaria. A partir del análisis etnográfico se evidencian elementos para reflexionar la formación continua docente: la multiplicidad de significados contenidos en las prácticas y supuestos compartidos por los docentes, el trabajo conjunto entre docentes para la explicitación, confrontación y negociación de tales significados, el compromiso docente con los desarrollos de sus estudiantes.

Palabras clave: Formación de profesores en servicio. Práctica docente. Planeación cooperativa. Etnografía.

\footnotetext{
* This article is adapted from the doctoral thesis of Liliana Tarazona Vargas under the direction of Antonia Candela.

${ }^{1}$ Universidad Pedagógica Nacional (UPN), Departamento de Física, Bogotá, D. C., Colombia.

E-mail: <ltarazonav@pedagogica.edu.co>.

${ }^{2}$ Instituto Politécnico Nacional (IPN), Centro de Investigación y Estudios Avanzados (CINVESTAV), Departamento de Investigaciones Educativas (DIE), Ciudad de México, México.
} 


\section{Introduction}

Different researchers have contended that teacher formation, especially for in-service teachers, ends up having very little impact on everyday practice when it revolves around passing on teaching techniques and transmitting content and standardized practices, particularly when the teachers are not convinced of the underlying premises and the process is imposed on their practice (COPELLO; SANMARTÍ, 2001). The research has pointed out the need for formation programs to take, as a point of departure, teaching knowledge obtained in everyday practice (MERCADO, 2010; NÚÑEZ; ARÉVALO; ÁVALOS, 2012), and to recognize teachers' responsibility for their own professional development (LUFT; HEWSON, 2014). Focusing formation work on teaching practice has been an important step forward in training for in-service teachers.

Incorporating practice into formation implies assuming that teachers learn and construct knowledge in their everyday work, and that it is essential for their formation to engage with that knowledge (IMBERNÓN, 1994; MERCADO, 2002; ROTH, 1998). In this way, teachers are seen as agents, as reflective professionals with good judgment for making decisions about their practice (IMBERNÓN, 2011); they are considered perfectly capable of mobilizing both themselves and elements of their practice to other contexts. These considerations have led to novel formation proposals: processes of peer interaction to improve practices within the school itself, mobilizing practice to the formation context (reports, videotapes, narrations), participating in action-research processes, systematizing and analyzing classroom experiences to correct problems, among others. In most cases these proposals involve teachers working together as a condition for questioning, challenging, constructing and expanding the ideas that guide their own practice; the proposals also often include a role for advisors (ÁVALOS, 2011; CHUNG; MAK; SZE, 1995; ESPINOSA, 2014; GONZÁLEZ-WEIL et al., 2014; LUFT; HEWSON, 2014; NÚÑEZ; ARÉVALO; ÁVALOS, 2012; VOOGT et al., 2011).

This article looks at teachers' participation in a graduate-level training program that focuses on teachers' practice. It analyzes the process as experienced by two physics teachers who, within the context of a master's degree program they are studying, jointly plan a teaching proposal that they then implement in their respective classrooms, and subsequently reflect on the obtained results. These activities, although conceived as an integral component of teaching practice, were foreign to both teachers, partly due to the conditions of the formation context, which called for joint, detailed work and the explicit specification of certain products. In this sense, this article shows that establishing links between two contexts where different practices and meanings are produced - in this case, the classroom and graduate studies - is not a simple task.

The conditions of everyday teaching practice in most cases do not match the conditions of teacher formation programs. For example, the times defined by school calendars, the material resources, the administrative structure, the conditions for conscientious planning, teaching experience, among others, are just some of the aspects that tend to differ significantly. Moreover, the exercise of self-analysis and of questioning or contrasting different teachers' knowledge and routines could be difficult to carry out, especially when the formation context's conditions for producing sense and meaning diverge from those that shape everyday practice (BRYAN, 2012; MERCADO, 1997; PUTMAN; BORKO, 2000).

This article seeks to communicate some results of a wider ethnographic research project that set out to document and analyze the participation of the teachers taking these 
training programs and the role-played by joint planning in modifying classroom practices. Our intention is to contribute to the discussion of how connections can be created between everyday classroom practice and planning in the in-service training program, by analyzing the teachers' participation in the process without the intervention of any instructional prescription from outside the program.

\section{Between teacher formation and everyday practice}

The fieldwork for the research was carried out in the context of a Master's Degree program in Science Teaching at the National Pedagogical University (UPN in Spanish) in Bogotá. Even though the program in all of its activities seeks to relate teaching practice in the classroom to the context of formation in the Master's Degree program, one seminar in particular makes explicit the need for teachers to move between the two contexts. The course encourages teachers to work together to come up with an instructional proposal that will allow them to address an issue, conceptualization, skill, etc., of their choice in the classroom. Subsequently they are asked to tell what happened in the classroom when they implemented the proposal, to organize their students' responses and to propose categories that will help them describe the process in the form of a narration. These activities were carried out in teams made of at least two teachers studying for the Master's Degree and one advisor (professor of the program).

For the purpose of our study, we turned to ethnography because as a theoretical perspective and methodology it allows the detailed description of what happens in the process to shed light on the process itself, from the participants' viewpoint. In this way, before analyzing the situations in the light of the theories or prescriptive standards of training processes, the actions are interpreted in terms of the local meanings that the participants construct when they act and interact discursively (ROCKWELL, 2009). In this sense, units of analysis were established that would facilitate an understanding of the whole process: the planning, the implementation, and the narration of the implementation; along with other units that would allow for finer analyses, for example, of discursive interactions. It can be assumed that spoken interactions are moments when the meanings of constructed situations and actions are made explicit. Each participant, depending on the situation, constructs possible versions of "the world" that make it possible to interact with others, and at the same time to negotiate and reconstruct the meanings of actions (CANDELA, 1999; EDWARDS, 1996).

Following this perspective, observations and recordings (written, audio and video) were made of the process as experienced by two physics' teachers (Héctor and Rafael) together with an advisor during the activities of this master's seminar. The initial training of both teachers is a university degree in physics and they have 12 years of experience teaching this discipline at the secondary level, however they can be consider young teachers (around 30 years). They both teach in public schools but at different socioeconomic contexts. Héctor's school attends students from low-income families, while Rafael's school attends middle class pupils; at the same time they are studying the Masters' degree. The advisor is a woman with a Master's degree in physics and $\mathrm{PhD}$ in education. She has experience teaching physics in secondary and university level.

The team met over the 10 weeks that the seminar lasted, during which time they jointly planned an instructional proposal aimed at "enriching the students" explanations about floating bodies." In this course, the teachers also narrated the results of the process of implementing 
the proposal. Each teacher put the teaching proposal in practice over 6 classes, in his own classroom. Both teachers decided to aim the proposal at $10^{\text {th }}$-grade students (students between the ages of 16 and 18 years old who were taking Physics for the first time).

This article analyzes some extracts of the talk that occurred during the planning, implementation and narration stages. These analyses are not intended as an evaluation of the work that each teacher and the advisor have done, or of the master's program. The intention is to document and understand what goes on in the seminar and in the classroom when each teacher participates in both contexts simultaneously, and to describe the characteristics of these training processes. The hope is that the research will lead to an understanding of the complexities of implementing an instructional proposal, even when the teachers themselves design it, and the unlikelihood that it will lead to similar dynamics in the two classrooms.

\section{Teaching practice and participation}

To make the analyses presented here, it was necessary to establish relationships between the data and certain theoretical categories that would open a dialogue between the process described and the field of teachers' training, these categories being practice and participation.

Practice is a category that can be defined as the opposite of theory, or as the possibility of putting theory into action, the technique perspective that sets the orientation of the teaching training. It can also be seen, however, as a synthesis of ideas, reflections, theories and actions. Teaching practice is a social practice, i.e., "the construction of products, representations, activities, knowledge, etc., while working with others and responding to specific situations" (TARAZONA, 2016, p. 28).

According to Wenger (2001), practice is not just action; it implies commitments that drive interactions with others, the construction of joint undertakings, and the negotiation of meanings. In other words, practice is not completely defined or static; it is open and dynamic, which is why it cannot be prescribed by norms. In this sense, teaching practice has two characteristics: it is unpredictable and unspoken. The unpredictability has to do with the impossibility of foreseeing the actions that might occur in an interaction and the responses that can be formulated to these actions, and therefore, the impossibility of predicting strategic actions to be taken in order to adapt or adjust the participation to the concrete situations (ERICKSON, 1982). And the unspoken character is understood as the impossibility of putting into discourse all the elements involved in the decisions and actions that take place in the interaction (ROTH, 1998).

Participation is understood as the experience of creating ties to others in the construction of shared commitments and tasks. Wenger (2001, p. 80) argues that participation implies "action and connection," i.e., participation includes not only the actions undertaken to complete a task, but also the recognition that these actions are inherent to a commitment to others and to jointly defined undertakings. To quote this same author, "participating does not imply only equality or respect" (WENGER, 2001, p. 81); it also encompasses conflict and competition, along with collaboration, because participation involves contributions from different levels of control and knowledge of shared resources (beliefs, languages, meanings, etc.). So, one characteristic of participation is the negotiation of meanings, i.e., expanding, reinterpreting, modifying, confirming shared meanings that converge in the actions and contributions made by the participants (WENGER, 2001). 


\section{Joint planning and the construction of mutual commitment}

During five seminar sessions, the teachers and the advisor worked together to design and plan an instructional proposal. Some of the aspects undertaken in this stage were: (a) the teaching purpose of the instructional proposal: to enrich students' explanations of floating bodies; (b) elements of the content to be covered: the phenomenon of floatation; (c) perspective on teaching intervention; and, (d) design of the elements to be promoted in the classroom: questions and experiments.

This joint planning exercise called for certain elements that would play a role in the classroom to be made explicit and detailed. This characteristic of the project was a far cry from the way both teachers generally planned their classes. In their words, the planning in their practice was an open, flexible and unspoken process. That is to say, no one determined ahead of time all the details of the activities to be carried out in the classroom, because the way the classes were run had more to do with the interaction with the students than with a pre-defined plan. In this sense, joint planning was a new process for both teachers.

In order to present some of the elements that went into the configuration of the joint planning of this formation process, an analysis is presented of a couple of interactions between teachers and the advisor during the definition of the first activity of the proposal.

\section{Personal tendencies, mutual recognition and the negotiation of meanings in planning}

In planning, the teachers and the advisor set up the experiment and the question as resources for examining certain physical phenomena in the classroom. Physics teachers share these resources. These resources came from the everyday practice and knowledge that circulate in secondary school science teaching at the Colombian context. However it was necessary to design these resources for the proposal; their detailed definition, taking into account the wide variety of meanings that they could have. So, when it came time to discuss the right moment to formulate the questions, or the type of instructions to guide the experimental work in the classroom, the teachers gave voice to personal positions regarding the meaning of these resources within the instructional proposal they were planning. The following fragment is part of the discussion about the type of instructions to be given for the first activity of the proposal:

\section{Fragment 1}

Advisor: The explanation will depend on the question, so it's important to be very careful in formulating the question that you're going to ask the kids. [...]

Héctor: Why does a piece of wood float?

Rafael: But we could also have no question at all. We could just tell them, «Explain what you see», period.

Héctor: Using the word why

$[\ldots]$

Rafael: Héctor, [the teacher raises his voice emphatically] what I think is that yes, include that in a follow-up activity, OK? Both the questions the kids bring up 
and the ones we ask them. But I think that in the first stage all they need to hear is «Explain this.» $[\mathrm{A} 3 \mathrm{HRP} 24]^{3}$

This discussion about the best way to pose a precise question underscores the experience that each teacher has about involving students in activities. In this exercise, each teacher articulates a particular tendency for giving instructions that will get students to explain the observed phenomenon. Héctor proposes a question to point students toward thinking about the causes of flotation: "Why does a piece of wood float?" Rafael, for his part, emphatically and directly exhorts students to explain the phenomenon: "Explain this," leaving unsaid exactly what the students are supposed to explain.

There seems to be some contention over the meaning of the question within the planned activity. For Héctor, the question would get the students to participate in explaining the causes of the phenomenon of floatation. Rafael feels the question would limit the students' participation, because they might offer their explanations only if asked to. This difference of opinion brought to the surface an underlying tension that proved to be decisive in the planning of the first activity, in terms of whether or not to determine the question in advance. The interaction in Fragment 1 continued as follows:

\section{Fragment 2}

Advisor: But what I want to say is that the kids don't know what it means to explain, as we understand it.

[They remain silent for a moment]

Advisor: and they end up simply describing.

Héctor: On the other hand, with the question they'll know to focus on a container.

Advisor: I feel the question is important.

Héctor: a container, a piece of wood, and that's it.

Advisor: I think it is important to use the word why, as a way of demanding.

Rafael: In that case, it would be: Why does this float?

Héctor: Why does the piece of wood float?

Advisor: $=$ Why. Yes. [A3HRP25]

The advisor's intervention triggered a negotiation of the meaning of questions within the proposal. On the basis of the purpose of the activity (to get the students to explain the floatation of a piece of wood in water) and Rafael's proposal not to use questions, the advisor wondered what the students would understand if they were asked to explain a situation without more guidance as to what was expected. Up to that moment the teachers had not asked

\footnotetext{
${ }^{3}$ In the spoken interaction fragments, the following transcription notations are used: [...] Parts of the utterance were eliminated because they are not relevant to the analysis at hand; «abc» Interventions that the participants indicate they would make (or made) at another moment; = Speech linked to the previous utterance without the pause that is habitual between interventions; [A3HRP25] Fragment code.
} 
themselves whether the students "knew" what it means to explain something. In this sense, the instruction proposed by Rafael could lead to unexpected answers, such as students describing what they observe without explaining the general phenomenon.

In response to the advisor's intervention, the teachers agreed to formulate a question for the activity, but this does not imply that each of them assigned it the same meaning. While the difference between meanings is not stark, the meaning that each teacher gives the question implies a way of approaching the work that they will be promoting in the classroom, as we will see below.

According to Olson (1992), the meaning assigned to actions is linked to their purpose; this makes it important to bear in mind how each teacher was constructing the purpose of the planned activities. Héctor wanted the activities to guide the students' explanations, so the question served to focus their attention on the setup of the experiment and from there they would derive their explanations ("with the question they'll know to focus on a container [...], a piece of wood, and that's $\left.i t^{\prime}\right)$. In other words, he was counting on the question to point the experimental work and the students' answers in the right direction. In Rafael's mind, on the other hand, the activities by themselves would be enough to get the students to autonomously construct explanations about the phenomenon, so the question needed to be one that would not direct the students' answers: "Why does this float?" The question should trigger autonomous thinking in the students.

What these interactions point out is that the joint construction of a teaching proposal led to the articulation of shared teaching concerns (for students to come up with their own explanations of physical phenomena), known classroom strategies (experiments and questions) and personal tendencies regarding teaching processes in the classroom (directed and autonomous). The tension between these tendencies compelled the teachers to articulate and negotiate the meanings of resources that teachers utilize in their day-to-day practice.

Wenger (2001) argues that the negotiation of meanings allows participants to expand, reinterpret, modify or confirm the meanings that participants deploy in a given practice. In this sense, the negotiation that took place in the joint planning enabled the teachers and the advisor to articulate and confront their tendencies regarding the best way to implement the proposal in the classroom. Furthermore, the negotiation made it possible for each teacher's contributions to be reinterpreted and expanded, as in the case of Rafael, who eventually came to see the question as a timely teaching resource for the first activity of the instructional proposal. In this case, the advisor's mediation and the mutual recognition of meanings assigned to the question gave rise to the explicit consideration of elements that had been left out of the picture previously. This enabled the participants to negotiate and construct the question as a part of the repertory of tools for the instructional proposal. Notwithstanding, this did not guarantee the construction of a single meaning for the question; as we saw, the teachers held on to the diverse meanings they associated with the planned resources.

While joint planning was not a part of either teacher's practice, it was possible to turn to elements of physics teaching that the teachers and the advisor could identify from their own experience. In this sense, despite the recognized difficulty of examining elements of everyday practice in the realm of discourse (ROTH, 1998), in joint planning this difficulty is eased because "when teachers participate jointly on an undertaking and negotiate meanings that they foresee as involved in their teaching practice" (TARAZONA, 2016, p. 113), it becomes necessary to identify elements of practice explicitly. 


\section{Making connections between planning and everyday classroom practice}

Once the first session of the instructional proposal was planned, and certain elements to be considered for upcoming sessions were defined, both teachers took the planned activities to their classroom. Implementation involved the mobilization of the proposal from a context of practice to a different context (from the seminar to the classroom). In each of these spaces the teachers were linked in a particular way by having different identities: as master's degree students in one and physics teachers in the other.

By analyzing teachers' participation in the classroom during the implementation of the planned proposal, we can identify the implications of this dual identity in the training process. For example, the implementation implied that each teacher had to do additional individual planning of the strategies for presenting the activities to the students, since there were aspects of the work that were not considered during the joint planning. So while Rafael put together work guides that specified the questions and the experimental setups that the students were to work with, Héctor gave oral instructions right before the activities. These decisions were determined in part by the conditions of the class: effective work time, lab resources and the students' way of participating. We could look at this aspect in greater depth ${ }^{4}$, but what interests us the most here is to analyze the teachers' participation during the development of the activities, i.e., in their interaction with their students.

In the following section, we analyze fragments of classroom interaction that occurred during the implementation of the first session of the proposal, pointing out some of the most significant elements of the teachers' participation over the six classroom work sessions required for the implementation of the planned instructional proposal.

\section{Tension between the students' participation and the implementation of the planned activities}

Each of Rafael's classroom sessions started the same way: the students formed teams, the teacher gave out the work guide and the material for the experiment and asked them to answer the questions that appeared on the guide. He also emphasized the freedom the students had to answer them, that he would not answer them himself or grade their ideas. This made clear the teacher's interest, which he had expressed since the planning stage, in encouraging students to construct their own learning autonomously from that they observed in the floatation experiment.

The students responded to this autonomy by coming up with experimental situations different from the one specified in their work guide. For example, in the first session the students were supposed to answer the question: Why does a piece of wood float? One team, however, made a paper boat and floated it in the same container of water the teacher had set up for them with the piece of wood. The group members told the teacher that wood floats the same way their paper boat did, or a cork would. Upon this comment Rafael intervened as follows:

\footnotetext{
${ }^{4}$ We published a previous article with an analysis of the way the instructional proposal was mobilized (TARAZONA; CANDELA, 2016). 


\title{
Fragment 3
}

\begin{abstract}
Rafael: [...] as I told you, you took the experiment where you wanted to go. Alumnas: Yes.

Rafael: I mean, you bandled it the way you wanted to. But now, first of all, you bave to answer why this floats (pointing to the piece of wood); it doesn't matter whether you made a comparison or not. And second, you can talk. among yourselves as much as you like, ask each other questions, answer back, whatever you want. [S1RP5]
\end{abstract}

While Rafael recognizes the situation proposed by the students as an autonomous experimental activity, he then asks them to focus on the flotation of the wood. He specifically suggests that they observe the setup of the experiment and on that basis answer the question Why does this piece of wood float? In this way, the experimental situation proposed by the teacher, consisting of the work guide and the material given to the teams, was the only resource for answering the question.

The students' autonomous initiative, encouraged and expected by the teacher, caused some tension with respect to the plan for the class, because it led to activities that were considered outside the proposal. The teacher resolved this tension by directing the students' actions toward the questions specified in the guide. In this way the teacher gave priority to the contents of the work guide over the contents of the students' own actions.

The role Rafael assigned to the guide might have reflected his interest in testing the planned proposal. This implied, on the one hand, that his tendency toward the autonomous construction of explanations took a back seat during the development of the activities. And on the other hand, no effort was made to forge a joint commitment with the students to making sense of the activities in the proposal. That is to say, the teacher, feeling his commitment to the program of the master's degree seminar, responded in the classroom by "applying" the proposal with minimal modifications.

We do not mean to insinuate that the teacher suspended his know-how and concerns as a teacher. He drew on them to guide the students' participation toward the desired objective. However, the implementation of the proposal might have detached him from his everyday teaching practice.

\section{Continuity between classroom dynamics and planning}

Héctor's participation in his own classroom during the implementation of the planned activities contrasted with Rafael's. In response to the situations, experimental procedures and questions that his students bring up, Héctor's interventions aimed at following the logic of their proposals: he interspersed questions that were not planned in the seminar and facilitated experimental material that had not been considered previously. The following fragment helps to illustrate this process. The interaction took place during the first session of the implementation of the proposal. The students were working in teams around the floating wood that the teacher had provided. The teacher approached one of the groups (G1); they stated that if the block of wood were heavier, it would sink. A member of another group (G2) is standing next to the teacher. The teacher intervenes: 


\section{Fragment 4}

Héctor: Let's put in a bigger piece. [He takes a long piece of wood out of a bag and shows it to the G1 students] Will this float? [He hands the piece of wood to G1].

Student: Yes, it still [floats] [G2 student]

Héctor: Will it keep floating? [addressing G2]

Student: Could it be that the weight doesn't matter and it will keep floating? I say the weight doesn't matter

Héctor: The weight of what?

Student: Of the piece of wood. Do you have a bigger one in there? [The teacher looks inside the bag and hands him a long piece]. [S1HP8]

In this case, the planned experimental situation (the floatation of a piece of wood) is expanded on account of the statement made by the team of students (floatation depends on weight) and the teacher's intervention suggesting that they corroborate the statement experimentally. In other cases, it was the students who asked the teacher for additional material to test the explanations they were constructing.

This type of interaction happened over and over again in Héctor's classroom: the teacher gave feedback to the students' activity (for example, by providing material that was not considered in the original planning). He improvised experimental situations that tried to coordinate the students' work and initiatives with the content that had been planned for the proposal. In this way, the experiment became an activity that was collectively constructed in the classroom. However, the teacher's feedback led to a particular form of observation, manipulation and construction of the students' explanations which eventually led to controlled variables, exactly as planned for subsequent sessions. In this sense, the classroom activity went in unexpected directions without losing track of the planned objectives. The teacher made connections between the logic of the students' reasoning and the approach to the phenomenon as planned in the master's degree seminar.

Improvisation is a teaching resource that forms part of day-to-day practice. By using it, Héctor reconciles student participation with his tendency toward the directed construction of explanations, which he made clear in the planning stage. In this sense, "implementation could be seen as a way to coordinate elements from two separate undertakings: joint planning and individual experience teaching physics in the classroom" (TARAZONA, 2016, p. 153).

These analyses show that in both classrooms, the teachers' dual commitment to the formation process and to their own personal tendencies for improving the learning processes had an impact on the implementation of the instructional proposal. Moreover, in order to cope with the unpredictability of the students' participation, the development of the proposed activities brought out teaching know-how that was not discussed during the planning stage. In this sense, both teachers drew on their experience and particular approach to teaching.

Thus, the affiliation with two different styles of practice and contexts, which the planning had tried to reconcile, ended up generating tension that the two teachers resolved differently: Rafael separated the two styles of practice and reproduced the proposal in the classroom as planned, while Héctor brought the styles together by following the logic of the students' participation in order to adjust the activity while remaining faithful to the original plan. 
Even though the teachers themselves in line with their concerns and using their resources, in the end, designed the instructional proposal different proposals were implemented. This points out the impossibility of achieving similar teaching practices by promoting a single proposal. Teaching know-how, personal tendencies, and teaching conditions have a decisive impact on the way a proposal is put into practice (CHUNG; MAK; SZE, 1995; ESPINOSA, 2014; TARAZONA; CANDELA, 2016). And it cannot be any other way, because the meaning of the proposed activities and of the resources mobilized in the classroom is reinterpreted, modified and expanded in the interaction among all the educational actors in the classroom.

\section{Joint construction of narratives about practice}

The last part of the process undertaken in the seminar consisted of systematizing the results of the instructional proposal. The oral narration of what occurred in each classroom during the implementation of the proposal was the strategy that the teachers and advisor came up with to carry out this stage. It is interesting to highlight the situations and resources that the teachers considered relevant to mobilize from the classroom to the seminar by way of their narrations: descriptions, assessments, theoretical references, other classroom experiences, etc. In the final analysis, it was these elements that showed that teaching practice was playing the leading role in the seminar.

It must be recognized that the exercise of narrating what happened does not necessarily account for everything that can be observed in a classroom; it can help, however, to draw out the meanings that each teacher assigns to his experience and that he considers relevant enough to bring to the university. The narration forces each teacher to reconcile that which he considered worth sharing from the implementation with the repertory of meanings shared in the seminar during the planning stage. In this sense, both the teacher and the advisor had elements to participate in the joint construction of the narrations.

The following section includes the analysis of certain spoken fragments taken from this stage, with the intention of identifying elements of the teachers' participation in the joint construction of narrations about teaching practice.

\section{Mobilizing students' participation}

The main topic of the narrations that the teachers constructed about their implementations centered on the students and their response to the activities, which relates to one of the most important currents motivating them to improve their work as educators. The following fragment corresponds to Rafael's first narration about the implementation of the first session of the proposal. He starts out by commenting on his students' answers to the question $W$ hy does a piece of wood float? pointing out that they were limited to the word density. And he went on identifying some of the causes of this limitation:

\section{Fragment 5}

Rafael: The dynamic of the class really affects them. What I mean is that [the students] are used to the teacher providing them with everything, telling them to be quiet, telling 
them to do this activity. So they come in and start asking. There a lot of behaviorism in the school setting, from all the teachers, myself included. So, for example, the first thing [the students] ask before starting to work on the activity is: «Will we be graded?». That, unfortunately, is a significant limitation. [...] That's what I see. [A4HRP4]

This extract suggests that Rafael sees the classroom dynamics that have been constructed at his school as a constraint on trying out new ways of working. The students have apparently learned to respond to certain "behaviorist" routines that keep them from doing more autonomous work, which is what the teacher was hoping for with the activities of the proposal. This shows that the teacher sees the instructional proposal as innovative within the context of his everyday practice.

In the construction of this narration the teacher turned to his know-how about the kind of participation students usually engage in, as well as about the practices that characterize the school. These are used as resources that enable him to communicate his understanding of the results of the implementation. In this sense, teaching know-how is used to read what goes on in the classroom, and to make sense of new teaching proposals (TARAZONA, 2016).

In the narrations that Rafael constructs, he assumes a commitment to changing dayto-day dynamics by implementing an instructional proposal that will encourage greater student participation in the construction of knowledge within the classroom. This position might reflect the purpose constructed in the context of the seminar, or his narration could very well be a one-sided story, a cover-up (CONNELLY; CLANDININ, 1995) of his tendency to direct his students' participation in a very behaviorist way.

Even though both teachers narrated what happened in their classroom by mobilizing the answers given by their students, the aspects recalled by each teacher did not coincide. For example, Rafael related his students' answers in terms of the difficulties and limitations they had, while Héctor underscored the actions and proposals that his students came up with, enriching the planned activities.

The distinction between the narratives made it possible for the teachers to engage in dialogue, which in turn called for the analysis of other elements of each teacher's implementation that were not mentioned explicitly. This is presented in the next section.

\section{Reconstructing the implementation jointly}

In the context of the seminar, the exercise of narrating what happened in each classroom during the implementation of the proposal was framed as an activity of joint construction of the situations mobilized from the classroom seminar at the university. The following fragment provides evidence of this process. The interaction occurs after the teachers have described the answers their students gave during the first activity.

\section{Fragment 6}

Rafael: Well, the thing is that some [of the previously planned] activities seem like they were aiming at those answers that [Héctor's students] gave. [...]. Maybe at some point you [Héctor] gave them some kind of bint: «think about size, shape». 
You never told them anything like that? Because it seems odd that my [students] never said anything about size, or shape, or any of that.

Héctor: Of course, [the students] started out by asking me. I even had a few pieces of wood with me [...] and some of them went and got some and put three in the water, and I said: «No, no, it's just one block, later». But I did say to them: «OK, what does it depend on? Size, or what? Shape?». [A5HRP16]

Recognizing that each group came up with different answers led Rafael to question, or at least to ask for more information about his colleague's narration. The emphasis that Héctor placed on his students' answers (answers that corresponded to the activities of the proposal) was not enough for Rafael to understand everything that had happened in that classroom. This motivates him to ask Héctor to describe aspects that he had not mentioned: the way he proposed the activity in the classroom, i.e., the kind of teaching intervention he was employing. Héctor accepts the questioning, and complements his narration with other elements of what happened in his classroom.

Both teachers' interventions can be read in terms of their personal tendencies. Rafael, with his focus on the autonomous construction of explanations, might feel that the answers given by Héctor's students were conditioned by his colleague's interventions in the classroom. For his part, Héctor describes the events that took place in the classroom, recognizing that in response to the students' initiative, he decided to intervene by formulating additional questions, which allowed them to expand on their answers.

The elements that each teacher integrated into his narration gradually took shape as resources from which to intervene in this stage of the seminar. The following fragment, which exemplifies this aspect, occurs in the session following the one when the previous fragments took place. Rafael composed a text describing what happened in his classroom during the first session in which the proposal was implemented:

\section{Fragment 7}

Rafael: [reading] [the students] were asked only one question, and since everything depends on what is asked of them, many felt they were finished in no time because they didn't have much to say about the topic [he finishes reading]. That was a conclusion; it sort of cuts across what happened with Héctor and me. Because one of the things that made a difference was that he asked another question. So, we can say that the kind of questions you ask is a very important point. [A5HRP4]

The narrations composed by the teachers highlight the mutual recognition of the contributions that each one made to the process of constructing an alternative instructional proposal. The description made by Héctor, which involved asking the students questions in addition to those that were planned, highlights one aspect of teaching practice that Rafael recognizes: the type of questions formulated in the classroom relates to the content being covered and the time available. This can be interpreted as indicating that Rafael is willing to include teaching actions described by his colleague, as he looks to encourage student participation similar to what Héctor presents. 
It is interesting to point out that at different moments in the seminar, the teachers' and advisor's interventions served as mediation to establish connections between the stages of the process that were reflected in the narrations: the objectives and the assumptions underlying the planned activities, the personal tendencies regarding the best way to construct explanations in the classroom, etc. Narrating their teaching experience in the context of the seminar forced the participants to make use of the repertory of meanings that they had constructed in their joint process. And in that way the narrations were constructed jointly, and along with them, the training process itself, through reflection on practice as seen in the mirror of a pair of teachers with similar interests.

\section{Final reflections}

The analyses presented here offer different elements for reflecting on in-service teacher training processes that try to make connections to everyday teaching practices.

One element of reflection is the difficulty, if not the downright impossibility, of expecting similar practices even when agreements are reached and proposals made among teachers with similar academic and workplace backgrounds. Teaching physics, and the intention to innovate this practice by involving students in the construction of explanations, were points in common from which two teachers put together a single instructional proposal, confident that in this context they could find shared meanings. In the articulation of the assumptions contained in the proposal, however, the knowledge involved in the implementation and work dynamics in each classroom laid bare the wide variety of meanings contained in shared practices and assumptions related to the teaching of physics.

In this sense, the teachers' participation in this process involved both joint work and personal definition, a collaborative relationship and the articulation of discrepancies, a general characterization of the teaching of Physics and the definition of contextual situations that define each teacher's practice. It is also possible to discern the role played by the articulation of resources and mechanisms developed by a pair of teachers when they put their joint proposal into practice. When peers confront the results they have obtained in classroom implementation, they open up the possibility of identifying their own problems, along with resources for dealing with them. It would seem to represent a very useful way for teachers to see themselves in a kind of mirror and come up with ideas for improving their practice. This is the reflection process that Rafael went through when he concluded that he should incorporate more questions to encourage interaction in the classroom, as a way of achieving better results in terms of student participation and learning.

These points in common and the tensions that characterized them arose together with the recognition of individual contributions, teaching know-how and tendencies. This did not imply the imposition of meanings on practice. Instead, there was evidence of negotiation of meanings: with their students regarding the undertaking that the teachers had defined jointly, as well as in the exercise that each teacher carried out to make sense of the planning when it came time to implement it.

Another element that can be derived from these analyses is the importance of the commitments that orient the teachers' participation in the training process. One of them is 
their commitment to their students, evident both in the planning of activities that trigger certain processes in the classroom, and in the way these activities are presented to encourage student participation. It can also be seen in the aspects they choose to emphasize in their narrations, where they try to assess the results of the implementation on the basis of the students' answers.

Also related to this commitment was each teacher's tendency regarding the construction of explanations in the classroom. In spite of the processes of negotiation and joint construction between the two teachers, they were committed to ideas that they considered to be outside everyday practice, but that they felt would enhance their teaching processes. This was a commitment constructed by the teachers themselves that went beyond the university and impacted their decisions about feasible changes to teaching practices.

The teachers' participation also manifested their dual commitment as students and as Physics teachers. Their rigidity or flexibility in mobilizing elements between the two contexts depended on the role that each teacher assumed and the way he resolved the tension between the planning objective and the dynamics in his classroom. In this sense, the connection between everyday practice and the training process partly depends on the commitment and the tension that the teacher constructs in the mobilization of elements between the two contexts.

This conclusion coincides with that of other researchers who have suggested that when it comes to in-service teacher training, the participants need to be involved in their own learning, for example, by taking part in planning and evaluation processes, and by defining and solving teaching problems (BRYAN, 2012; ESPINOSA; MERCADO, 2009; GELDENHUYS; OOSTHUIZEN; 2015; GONZÁLEZ-WEIL et al., 2014; JOHN, 1991; LUFT; HEWSON, 2014; VOOGT et al., 2011). What seems clear from the analyses presented here is that this participation involved a commitment by each teacher to a particular way of promoting the construction of explanations in the classroom, as well as a commitment to the joint undertaking defined in the seminar. Therefore, in order to put teaching practice at the center of a joint training process, conditions must be generated for the construction of individual and shared commitments.

The use of the planning and implementation of teaching proposals as mechanisms for teaching performance evaluation is another worthwhile element for reflection. On the one hand, we can say that planning does not reflect all the considerations and know-how that teachers draw on to prepare an activity for their students. Even when the planning process and its construction are undertaken collectively and with the support of an advisor, it seems impossible to include all the elements that teachers might consider before taking it to the classroom or that they can improvise during its implementation. Thus, planning cannot guarantee that implementation will go entirely as planned. Even when it is the teachers themselves who plan and implement the proposal, the multiple meanings and methods that can develop in the classroom make it impossible for the planning to guarantee specific teaching practices. This shows that planning is a very poor and inappropriate mechanism for evaluating teaching.

This paper shows the importance of teachers working together on planning and narration. The main benefit went beyond the imposition and development of one specific practice; it enabled the teachers to recognize the conditions in their classroom and their own personal tendencies when it comes to teaching, and how these factors have an impact on what goes on in the classroom. This gives teachers insight into their own practice, its possibilities and limitations, and how to enhance it in the process.

Finally, we would like to underscore the contribution that an ethnographic study of an in-service teacher training process can make to the understanding of the possibilities and 
limitations of changing and improving teaching practice. The detailed description of what is said and done in the training process and the meanings of these practices as constructed by the participants themselves reveal characteristics that other intervention and analysis processes leave unexamined. It is important to understand the characteristics and complexities of the teacher training process in order to improve these systems and also acknowledge their limitations, given the unpredictable conditions, the diversity of teaching contexts, the variety of teachers' perspectives and their unspoken nature.

\section{Acknowledgments}

The first author thanks the grant received from the Mexican National Council for Science and Technology (Consejo Nacional de Ciencia y Tecnología de México) to develop this research.

\section{References}

ÁVALOS, B. Teacher professional development in teaching and teacher education over ten years. Teaching and Teacher Education, Oxford, UK, v. 27, n. 1, p. 10-20, 2011. Retrieved from < https://doi.org/10.1016/j.tate.2010.08.007>. Last accessed: 4 Oct. 2018.

BRYAN, L. A. Research on science teacher beliefs. In: FRASER, B.; TOBIN, K.; McROBBIE, C. J. (Ed.). Second international handbook of science education. Dordrecht: Springer, 2012. p. 477-495. Retrieved from <https://doi.org//10.1007/978-14020-9041-7>. Last accessed: 4 Oct. 2018.

CANDELA, A. Ciencia en el aula: los alumnos entre la argumentación y el consenso. México: Paidós, 1999.

CHUNG, C.; MAK, S.; SZE, P. Reflective lesson planning in refresher training programs for experienced physics teachers. Journal of Science and Technology, Dordrecht, v. 4, n. 2, p. 151-161, 1995.

CONNELLY, F.; CLANDININ, D. Teachers' professional knowledge landscapes: secret, sacred and cover stories. In: CONNELLY, F.; CLANDININ, D. (Ed.). Teachers' professional knowledge landscapes. New York: Teachers College Press, 1995. p. 3-15.

COPELLO, M.; SANMARTÍ, N. Fundamentos de un modelo de formación permanente del profesorado de ciencias centrado en la reflexión dialógica sobre las concepciones y las prácticas. Enseñanza de las Ciencias, Barcelona, v. 19, n. 2, p. 269-283, 2001. Retrieved from < https://www.raco.cat/index.php/Ensenanza/article/view/2174> . Last accessed: 4 Oct. 2018.

EDWARDS, D. Hacia una psicología discursiva de la educación en el aula. In: COLL, C.; EDWARDS, D. (Ed.). Enseñanza, aprendizaje y discurso en el aula: aproximaciones al estudio del discurso educacional. Madrid: Fundación Infancia y Aprendizaje, 1996. p. 35-52. 
ERICKSON, F. El discurso en el aula como improvisación: las relaciones entre la estructura de la tarea académica y la estructura de la participación social en clase. In: VELASCO, H.; GARCÍA, J.; DÍAZ, A. (Ed.). Lecturas de antropología para educadores: el ámbito de la antropología de la educación y de la etnografía escolar. 2. ed. Madrid: Trotta, 1982-2003. p. 325-352.

ESPINOSA, E. Prácticas de alfabetización en la primaria: apropiación docente de nuevas propuestas. México: Universidad Pedagógica Nacional: Horizontes educativos, 2014.

ESPINOSA, E.; MERCADO, R. La mediación social en la apropiación de una nueva propuesta para la alfabetización inicial. Educação e Pesquisa, São Paulo, v. 35, n. 2, p. 331-350, 2009. Retrieved from < https://doi.org/10.1590/S1517-97022009000200008>. Last accessed: 4 Oct. 2018.

GELDENHUYS, J.; OOSTHUIZEN, L. Challeges influencing teachers' involvement in continuous profesional development: a South African perspective. Teaching and Teacher Education, Oxford, UK, v. 51, p. 203-212, 2015. Retrieved from <https://doi. org/10.1016/j.tate.2015.06.010>. Last accessed: 4 Oct. 2018.

GONZÁLEZ-WEIL, C. et al. Principios de desarrollo profesional docente construidos por y para profesores de ciencia: una propuesta sustentable que emerge desde la indagación de las propias prácticas. Estudios pedagógicos, Valdivia, v. 40, n. esp. 1, p. 105-126, 2014. Retrieved from <https://doi.org/10.4067/S0718-07052014000200007>. Last accessed: 4 Oct. 2018.

IMBERNÓN, F. La formación y el desarrollo profesional del profesorado. Barcelona: Graó, 1994.

IMBERNÓN, F. Un nuevo desarrollo profesional del profesorado para una nueva educación. Revista de Ciências Humanas, Frederico Westphalen, v. 12, n. 19, p. 75-86, 2011.

Retrieved from < http://revistas.fw.uri.br/index.php/revistadech/article/view/343>. Last accessed: 4 Oct. 2018.

JOHN, P. D. Course, curricular, and classroom influences on the development of student teachers' lesson planning perspectives. Teaching and Teacher Education, Oxford, UK, v. 7, n. 4, p. 359-372, 1991. Retrieved from < https://doi.org/10.1016/0742051X(91)90005-A>. Last accessed: 4 Oct. 2018.

LUFT, J.; HEWSON, P. Research on teacher professional development programs in science. In: ABELL, S. K.; LEDERMAN, N. G.(Ed.). Handbook of research on science education. New York: Routledge, 2014, p. 889-910.

MERCADO, R. Un debate actual sobre la formación inicial de docentes en México. Revista Semestral da Associação Brasileira de Psicologia Escolar e Educacional, São Paulo, v. 14, n. 1, p. 149-157, 2010. Retrieved from <http://www.scielo.br/pdf/pee/v14n1/v14n1a16. pdf $>$. Last accessed: 4 Oct. 2018.

MERCADO, R. Formar para la docencia en la educación normal. México: Secretaría de Educación Pública, 1997. 
MERCADO, R. Los saberes docentes como construcción social: La enseñanza centrada en los niños. México: Fondo de Cultura Económica, 2002.

NÚÑEZ, M.; ARÉVALO, A.; ÁVALOS, B. Profesionalización docente: ¿es posible un camino de convergencia para expertos y novatos? Revista Electrónica de Investigación

Educativa, v. 14, n. 2, p. 10-24, 2012. Retrieved from < https://redie.uabc.mx/redie/article/ view/302>. Last accessed: 4 Oct. 2018.

OLSON, J. Understanding teaching: beyond expertise. Philadelphia: Open University Press, 1992.

PUTNAM, R.; BORKO, H. El aprendizaje del profesor: implicaciones de las nuevas perspectivas de la cognición. In: BIDDLE, B. J.; GOOD, T. L.; GOODSON, I. F. (Coord.). La enseñanza y los profesores I. Barcelona: Paidós, 2000. p. 219-309.

ROCKWELL, E. La experiencia etnográfica: historia y cultura en los procesos educativos. Buenos Aires: Paidós, 2009.

ROTH, W.M. Teaching and learning as everyday activity. In: FRASER, B.; TOBIN, K. (Ed.). International handbook of science education. London: Kluwer, 1998. p. 169-181.

TARAZONA, L. Los profesores entre la formación docente y la práctica cotidiana. Tesis (Doctorado en Ciencias) - Centro de Investigación y de Estudios Avanzados, Instituto Politécnico Nacional, México, 2016.

TARAZONA, L.; CANDELA, A. Comparación de la implementación de una propuesta didáctica diseñada por dos profesores. CPU-e: revista de investigación educativa, Xalapa, n. 23, p. 99-120, 2016. Retrieved from < http://www.scielo.org.mx/pdf/cpue/n23/1870-5308cpue-23-00099.pdf>. Last accessed: 4 Oct. 2018.

VOOGT, J. et al. Teacher learning in collaborative curriculum design. Teaching and Teacher Education, Oxford, UK, v. 27, n. 8, p. 1235-1244, 2011. Retrieved from <https:// doi.org/10.1016/j.tate.2011.07.003>. Last accessed: 4 Oct. 2018.

WENGER, E. Comunidades de práctica: aprendizaje, significado e identidad. Madrid: Paidós, 2001.

Artigo recebido em 18/02/2018. Aceito em 27/06/2018.

Contact: Universidad Pedagogica Nacional, Departamento de Fisica, Calle 72, \#11-86, Bogota 110221, Colombia. 